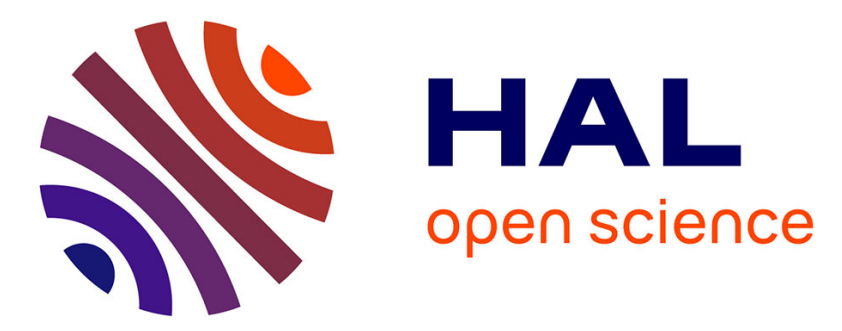

\title{
Grassland root demography responses to multiple climate change drivers depend on root morphology
}

Remi R. Pilon, Catherine C. Cochard, Juliette Bloor, Sandrine S. Revaillot, Estelle Kuhn Kuhn, Robert R. Falcimagne, Philippe Balandier, Jean-François J.-F. Soussana

\section{To cite this version:}

Remi R. Pilon, Catherine C. Cochard, Juliette Bloor, Sandrine S. Revaillot, Estelle Kuhn Kuhn, et al.. Grassland root demography responses to multiple climate change drivers depend on root morphology. Plant and Soil, 2013, 364 (1-2), pp.395-408. 10.1007/s11104-012-1371-8 . hal-00964730

\section{HAL Id: hal-00964730 https://hal.science/hal-00964730}

Submitted on 29 May 2020

HAL is a multi-disciplinary open access archive for the deposit and dissemination of scientific research documents, whether they are published or not. The documents may come from teaching and research institutions in France or abroad, or from public or private research centers.
L'archive ouverte pluridisciplinaire HAL, est destinée au dépôt et à la diffusion de documents scientifiques de niveau recherche, publiés ou non, émanant des établissements d'enseignement et de recherche français ou étrangers, des laboratoires publics ou privés. 


\title{
Grassland root demography responses to multiple climate change drivers depend on root morphology
}

\author{
R. Pilon • C. Picon-Cochard • J. M. G. Bloor • \\ S. Revaillot • E. Kuhn • R. Falcimagne • \\ P. Balandier • J.-F. Soussana
}

Received: 7 December 2011 / Accepted: 6 July 2012 /Published online: 21 July 2012

(C) Springer Science+Business Media B.V. 2012

\begin{abstract}
Aims We examine how root system demography and morphology are affected by air warming and multiple, simultaneous climate change drivers.

Methods Using minirhizotrons, we studied root growth, morphology, median longevity, risk of mortality and standing root pool in the upper soil horizon of a temperate grassland ecosystem for 3 years. Grassland monoliths were subjected to four climate treatments in a replicated additive design: control (C); elevated temperature $(\mathrm{T})$; combined $\mathrm{T}$ and summer precipitation reduction (TD); combined TD and elevated atmospheric $\mathrm{CO}_{2}\left(\mathrm{TDCO}_{2}\right)$.
\end{abstract}

Responsible Editor: Angela Hodge.

R. Pilon · C. Picon-Cochard $(\bowtie) \cdot J$. M. G. Bloor •

S. Revaillot $\cdot$ R. Falcimagne $\cdot$ J.-F. Soussana

INRA, UR874, Grassland Ecosystem Research Team,

5 chemin de Beaulieu,

63100 Clermont-Ferrand, France

e-mail: picon@clermont.inra.fr

E. Kuhn

INRA, UR341, Mathématiques et Informatique Appliquées,

78350 Jouy-en-Josas, France

P. Balandier

Irstea, Research Unit on Forest Ecosystems (EFNO),

45290 Nogent-sur-Vernisson, France

P. Balandier

INRA, UMR547 PIAF,

234 avenue du Brézet,

63100 Clermont-Ferrand, France
Results Air warming ( $\mathrm{C}$ vs $\mathrm{T}$ ) and the combined climate change treatment $\left(\mathrm{C}\right.$ vs $\left.\mathrm{TDCO}_{2}\right)$ had a positive effect on root growth rate and standing root pool. However, root responses to climate treatment varied depending on diameter size class. For fine roots $(\leq 0.1 \mathrm{~mm})$, new root length and mortality increased under warming but decreased in response to elevated $\mathrm{CO}_{2}$ (TD vs $\mathrm{TDCO}_{2}$ ); for coarse roots $(>0.2 \mathrm{~mm})$, length and mortality increased under both elevated $\mathrm{CO}_{2}$ and combined climate change drivers.

Conclusions Our data suggest that the standing roots pool in our grassland system may increase under future climatic conditions. Contrasted behaviour of fine and coarse roots may correspond to differential root activity of these extreme diameter classes in future climate.

Keywords Root dynamics · Warming · Summer precipitation reduction $\cdot$ Elevated $\mathrm{CO}_{2} \cdot$ Minirhizotron . Root lifespan · Cox proportional hazards

\section{Introduction}

Increased global carbon dioxide concentration, air temperature, and in many regions reductions in precipitation during the growing season, are some of the most important aspects of global change predicted to affect ecosystems in coming years (IPCC 2007). It is well established that warming stimulates plant growth 
and transpiration and affects soil environment through increased soil temperature and reduced soil water content (SWC) (Luo 2007). A reduction in growing season precipitation should further reduce SWC, while elevated $\mathrm{CO}_{2}$ may increase SWC through increased plant water-use efficiency (Niklaus et al. 1998; Wullschleger et al. 2002). In temperate regions, air warming and elevated $\mathrm{CO}_{2}$ are expected to both stimulate plant growth, while variability in precipitation may counterbalance aboveground growth responses via changes in SWC and in belowground processes (Norby and Luo 2004; Pendall et al. 2004). Thus ecosystem responses to multiple climate drivers are complex, which indicates possible non-additive effects of simultaneouslyoccurring factors (Shaw et al. 2002; Luo et al. 2008; Zhou et al. 2008).

It is expected that the roots and the below-ground compartment of grassland will be particularly affected by climate change as, in this ecosystem, most of the $\mathrm{C}$ is stored below-ground (Steinaker and Wilson 2005). However previous single-factor climate manipulation studies showed inconsistent patterns of root system response to warming and elevated $\mathrm{CO}_{2}$. For example, warming has been shown to stimulate root production and root mortality (Fitter et al. 1998, 1999; Bai et al. 2010) and reduce root biomass (De Boeck et al. 2007). Under elevated $\mathrm{CO}_{2}$, root production may increase (Fitter et al. 1996, 1997; Soussana et al. 1996; Higgins et al. 2002; Sindhøj et al. 2004; Milchunas et al. 2005a, b; LeCain et al. 2006; Anderson et al. 2010), decrease (Pendall et al. 2011) or show no response (Arnone et al. 2000; Dukes et al. 2005). For root mortality, elevated $\mathrm{CO}_{2}$ is also associated with an increase (Fitter et al. 1996, 1997; Milchunas et al. 2005a) or no change (Arnone et al. 2000; Higgins et al. 2002). Unlike root growth and mortality, root lifespan has faced little attention in climate change studies (Zak et al. 2000): Milchunas et al. (2005a) observed higher lifespan under elevated $\mathrm{CO}_{2}$, but Anderson et al. (2010) reported opposite results. Responses in root lifespan could be mediated by root diameter responses because of the tight link observed between these two variables (Eissenstat and Yanai 1997; Eissenstat et al. 2000; Gill et al. 2002). To date, relatively few studies have focused on the combined effects of warming, precipitation reduction and elevated $\mathrm{CO}_{2}$ on the below-ground compartment (e.g. Pendall et al. 2004; Wan et al. 2007). Available data indicate no root mass response to combined warming and elevated $\mathrm{CO}_{2}$
(Soussana et al. 1996; Kandeler et al. 1998; Shaw et al. 2002), while amounts of precipitation seem to modulate the positive effect of elevated $\mathrm{CO}_{2}$ (Milchunas et al. 2005b) and warming (Bai et al. 2010) on root growth. Overall, these findings reflect the complexity of interactions, occurring between direct and indirect effects of climate drivers on above and belowground processes. Furthermore, methodology can substantially vary between studies, concerning root dynamics measurement (Arnone et al. 2000; Luo 2007; Milchunas 2009) and the intensity of the climate factors imposed in experiments, e.g. range of air warming between 1 to $4{ }^{\circ} \mathrm{C}$, and a doubling of atmospheric $\mathrm{CO}_{2}$ concentration.

Root responses to climate change may be complicated by interactions occurring between plant physiological and morphological processes. In perennial grassland, standing root mass is the result of growth, mortality and decomposition processes that occur simultaneously and vary through season (Matthew et al. 1991; Steinaker and Wilson 2008; Garcia-Pausas et al. 2011). Moreover, root dynamics may be influenced by variability of root morphology within a root system, i.e. by the presence of different root classes. Although several authors have outlined the importance of separating fine and coarse roots (Fitter 1987; Jackson and Caldwell 1996; Craine et al. 2002; Waisel and Eishel 2002; Bahn et al. 2006; Pierret et al. 2007; PiconCochard et al. 2012), this has not been considered in recent climate change studies. Variation in root order is likely to affect root lifespan and main root functions including uptake and respiration in response to climate change (Eissenstat et al. 2000; Norby and Jackson 2000; Wan et al. 2007). Root diameter may be a useful proxy of root order, and a more easily measurable variable to determine how root turnover responds to climate change.

This paper reports root length growth and mortality (based on root disappearance, including decomposition) assessed with minirhizotron data obtained for the upper soil horizon of an upland perennial grassland as part of the Clermont Climate Change Experiment (Bloor et al. 2010). In this experiment, grassland has been exposed to four climate treatments in a replicated additive design since 2005: control (C), elevated temperature $(\mathrm{T})$, combined elevated temperature and summer precipitation reduction (TD), combined elevated temperature, summer precipitation reduction and elevated atmospheric $\mathrm{CO}_{2}\left(\mathrm{TDCO}_{2}\right)$. The $\mathrm{TDCO}_{2}$ treatment simulates projected climate conditions for the 
end of the century (ACACIA A2 scenario for 2080 in central France, IPCC 2007). Previous results from this study system showed a short-term stimulation of above-ground production under air warming, associated with an advance in flowering time for the dominant grass species (Bloor et al. 2010). This effect disappeared after 2 years, and a progressive decrease in aboveground production was observed with decline in grass abundance at the expense of legumes (Cantarel et al. 2012). Overall, the results obtained for the aboveground part suggested a main effect of air warming without marked impact of other climate drivers (precipitation reduction, elevated $\mathrm{CO}_{2}$ ). In this context, we studied how the root system responded to the climate treatments. We particularly evaluated how single or combined warming, summer precipitation reduction and elevated $\mathrm{CO}_{2}$ affect root dynamics by analysing abiotic (soil water content, air temperature, elevated $\mathrm{CO}_{2}$ ) and biotic (diameter classes) factors. In addition, complementary methods were used to quantify effect of treatments on median root longevity (Kaplan-Meier) and on risk of mortality induced by co-variates (Cox). We hypothesized that: i) root growth is stimulated by air warming like above-ground biomass, ii) long-term warming effects on soil water content reduction may decrease root longevity, fine roots being more sensitive than coarse roots, iii) seasonal dynamics of the grassland root system masks root responses to climate change.

\section{Materials and methods}

Study site and experimental design

A full description of the Clermont Climate Change Experiment design and study site is given in Bloor et al. (2010). Briefly, the study system is a native upland grassland, extensively managed, located in the French Massif Central area (control site C, Theix, France, $45^{\circ} 43^{\prime} \mathrm{N}, 03^{\circ} 01^{\prime} \mathrm{E}, 850$ ma.s.1.), subjected for 15 years to low-intensity sheep grazing without inorganic fertilisation (Louault et al. 2005). The grassland had relatively low species diversity (11 species) and was dominated by perennial grasses (more than $90 \%$ of phytomass) such as Agrostis capillaris, Elytrigia repens and Festuca arundinacea, but also included a small number of dicotyledon species (Stellaria graminea, Taraxacum officinale, Vicia sativa). The soil is a Cambisol developed on granite $\left(\mathrm{C}: \mathrm{N}, 9.8 ; \mathrm{pH}_{\mathrm{water}}, 6.2\right)$ and the climate is semi-continental with oceanic influences (mean annual temperature, $8.7^{\circ} \mathrm{C}$, mean annual precipitation, $780 \mathrm{~mm}$ on average of 1986-2002).

In November 2004, 80 monoliths $(0.5 \mathrm{~m} \times 0.5 \mathrm{~m}$, $0.4 \mathrm{~m}$ deep) were extracted from homogeneous, multispecies zones to avoid monoliths with a dominance of any one species. Botanical surveys at the start of the experiment indicated that the $0.5 \times 0.5 \mathrm{~m}$ monoliths contained $8 \pm 0.2$ species with the same composition on average as the field plot.

Monoliths were encased in stainless-steel boxes with drainage holes in the bottom. After a six-month on-site acclimatization period, the monoliths were randomised and assigned to experimental treatments: 20 monoliths were left at the control site $(850 \mathrm{~m})$ while the remainder was transferred to a lowland area $15 \mathrm{~km}$ away from the control site (lowland site, ClermontFerrand, France, $45^{\circ} 46^{\prime} \mathrm{N}, 03^{\circ} 08^{\prime} \mathrm{E}$, 350 ma.s.1.; mean annual temperature, $12.4^{\circ} \mathrm{C}$; mean annual precipitation, $575 \mathrm{~mm}$ ). Four monoliths were grouped together to form a single experimental unit $(1 \mathrm{~m} \mathrm{x} 1 \mathrm{~m})$. Five experimental units (i.e. 20 monoliths) and 15 experimental units (i.e. 60 monoliths) were allocated to the control and lowland sites, respectively. Units were placed in holes in the ground lined with a $0.5 \mathrm{~m}$-deep layer of volcanic gravel and a $0.4 \mathrm{~m}$ layer of subsoil $(0.4-0.8 \mathrm{~m})$ collected from the original monolith extraction site. The experimental units were placed $7 \mathrm{~m}$ apart to ensure that there was no risk of atmospheric contamination between $\mathrm{CO}_{2}$ enriched and ambient $\mathrm{CO}_{2}$ units.

Four climate treatments were applied in a replicated additive design with five replicate experimental units per treatment: control (C, control site), elevated air temperature $(\mathrm{T}$, lowland site, called warmed site thereafter), elevated temperature and summer precipitation reduction (TD, warmed site), elevated temperature and summer precipitation reduction plus elevated atmospheric $\mathrm{CO}_{2}\left(\mathrm{TDCO}_{2}\right.$, warmed site). Climate manipulations were based on ACACIA A2 climate change scenario projections for the area to the 2080 time-horizon (IPCC 2007) and corresponded to a $3.5^{\circ} \mathrm{C}$ temperature increase, a $20 \%$ reduction in summer precipitation, and atmospheric $\mathrm{CO}_{2}$ level of $600 \mu \mathrm{mol} \mathrm{mol}{ }^{-1}$. In our study, a mean annual warming of $3.5^{\circ} \mathrm{C}(\mathrm{T})$ was achieved by transplanting monoliths along an altitudinal gradient $(500 \mathrm{~m})$. To ensure the same water supply (i.e. precipitation) for the $\mathrm{C}$ and $\mathrm{T}$ treatments, rainfall was monitored at both sites and 
treatment $\mathrm{T}$ was irrigated weekly when necessary. For $\mathrm{TD}$ and $\mathrm{TDCO}_{2}$ treatments, reduction of summer (June, July and August) precipitation was achieved by intercepting rainfall with plastic roofs at $1.2 \mathrm{~m}$ above experimental units during rainfall events which lasted for 24 $48 \mathrm{~h}$ (for details see Bloor et al. 2010). The average precipitation reduction between $\mathrm{T}$ and $\mathrm{TD}$ and $\mathrm{TDCO}_{2}$, respectively, was 57, 78 and $56 \mathrm{~mm}$ in 2006, 2007 and 2008 , corresponding to a $20 \%$ rainfall reduction during summer period. Elevated $\mathrm{CO}_{2}$ was applied using a miniFACE (Free Air $\mathrm{CO}_{2}$ Enrichment) system following Miglietta et al. (2001).

Once all the experimental units were in place (on April 27, 2005), grass monoliths were cut to a height of $5 \mathrm{~cm}$ twice a year, in spring and autumn (end April and end October), to mimic the previous extensive management. No fertiliser was applied during the experimental period in line with previous management.

\section{Measurements}

Climate data (air temperature, ${ }^{\circ} \mathrm{C}$; precipitation, $\mathrm{mm}$; atmospheric $\mathrm{CO}_{2}$ concentration, $\mu \mathrm{mol} \mathrm{mol}{ }^{-1}$; net global radiation, $\mathrm{W} \mathrm{m}^{-2}$ ) were recorded every $30 \mathrm{~min}$ using two automatic dataloggers (Campbell Scientific, UK) installed at each site. Mean air temperature difference between the two sites was on average $3.3 \pm 0.1{ }^{\circ} \mathrm{C}$ over the three-year study period. Differences of monthly precipitation and cumulated potential Penman evapotranspiration (PET, mm month ${ }^{-1}$ ) were used as an index of water balance at both sites $(\mathrm{P}-\mathrm{PET})$. For the three year-study, cumulative $\mathrm{P}$ - PET was positive $(656 \mathrm{~mm})$ at the control site $(\mathrm{C})$ and negative $(-566 \mathrm{~mm})$ at the warmed site. Volumetric soil water content (SWC, $\mathrm{cm}^{3} \mathrm{~cm}^{-3}$ ) was measured every $30 \mathrm{~min}$, in each experimental unit, with a vertically inserted $20 \mathrm{~cm}$ long Echo dielectric capacity probe connected to a datalogger $\left(\mathrm{Ech}_{2} \mathrm{O}\right.$, Decagon Devices, USA). Soil water potential was determined from gravimetric soil water content (SWCg) measurements at field capacity (0.03 MPa) and at wilting point $(1.5 \mathrm{MPa})$ with a dewpoint meter (PotentiaMeter WP4, Decagon Devices, USA). The relationship between SWCg obtained by weighing 5-L pots and SWC given by the probes inserted in the pots made it possible to convert SWC to $\mathrm{SWCg}$, as: $\mathrm{SWCg}=$ 0.0948 Ln $(\mathrm{SWC})+0.4021, n=108, \mathrm{R}^{2}=0.81$.

Root data were obtained using a minirhizotron system (BTC-2, Bartz Technology, CA, USA). In April $2005,50 \mathrm{~cm}$ long transparent acrylic tubes were inserted at an angle of $45^{\circ}$ with one tube per monolith. However, only two tubes per experimental unit were analysed due to logistic constraints. Root images $(1.35 \mathrm{~cm} \times 1.8 \mathrm{~cm})$ were recorded from March 14, 2006 to January 15, 2009; images from the same localizations were recorded once a month during the growing period in 2006 and 2007, and twice a month from 2008 onwards. Three successive images were analysed from the main root zone $(5-10 \mathrm{~cm}$ depth) of each tube as described in Fitter et al. (1996).

Length, diameter and status (live, dead) of root segments were manually recorded using WinRHIZOTronMF software (V2005a, Regent Instruments, CA). For each date, length was modified according to growth event. Root diameter was determined after the first image and not modified thereafter; once grasses form roots, their diameter remains stable because there is no secondary growth in monocots (the majority of species in the community). Root length was determined per unit tube area $\left(\mathrm{mm} \mathrm{cm}^{-2}\right)$. Three diameter classes were defined: $\leq 0.1 \mathrm{~mm}, 0.1<\mathrm{D} \leq$ $0.2 \mathrm{~mm}$ and $>0.2 \mathrm{~mm}$, representing 22,55 and $23 \%$ of total root length across treatments. Root mortality was based on root disappearance following Johnson et al. (2001), and included time of decomposition. Root length growth and mortality rates were calculated as the difference in length of live and dead roots, respectively, between two successive dates divided by the number of days $\left(\mathrm{mm} \mathrm{cm} \mathrm{cday}^{-1}\right)$. Mean values by season are shown for each year. In addition, annual increment in new root length and root length mortality $\left(\mathrm{mm} \mathrm{cm}^{-2}\right)$ was calculated for 2006, 2007 and 2008 and for the three-year study period (2006-2008). Standing root length $\left(\mathrm{mm} \mathrm{cm} \mathrm{cm}^{-2}\right)$ was calculated as the difference between annual increment of new root length and root length mortality per year and for the three-year study period. All root variables were calculated as the average values of the two tubes present in the same experimental unit. A total of 10,360 root segments were drawn and an average of 2,590 root segments per treatment was used in the analysis.

\section{Statistical analyses}

Root length dynamics (growth, mortality rates, annual and total increment of new root length, mortality and standing root length) were analyzed using mixedmodel repeated-measures ANOVA. All interactions between treatment, diameter classes and season or 
year were included in the model. Treatments were compared using orthogonal contrasts and Tukey's honest significant difference (HSD) procedure. The effect of climate change drivers was analyzed as follows: warming effect, $\mathrm{C}$ vs $\mathrm{T}$; summer precipitation reduction effect under warming, $\mathrm{T}$ vs $\mathrm{TD} ; \mathrm{CO}_{2}$ effect under warming and summer precipitation reduction, TD vs $\mathrm{TDCO}_{2}$; simultaneous application of warming, summer precipitation reduction and elevated $\mathrm{CO}_{2}$ (2080 climate scenario), C vs $\mathrm{TDCO}_{2}$. When necessary, variables were square-root or log-transformed to normalize the data prior to ANOVA.

For estimation of root survival times, dates of root birth and root death were assumed to be the mid-point between recording dates before and after appearance and disappearance, respectively. Roots living beyond the last recording time were considered to be right censored, i.e. root survival time is known only to be at least as long as the time to the last recording. The proportion of roots surviving as a function of age was described by the Kaplan-Meier survival function, a non-parametric statistical technique which allows estimation of median longevity (Allison 1995). Median root lifespan was estimated for $50 \%$ of surviving roots. The comparison of the survival curves of groups is based on a formal non-parametric statistical test called the logrank test. All these statistical analyses were carried out using Statgraphics Plus 4.1 (Statistical Graphics Corp., Maryland, USA).

A Cox proportional hazards regression (Cox 1972; Allison 1995; Wells and Eissenstat 2001) was used to examine the effects of biotic and abiotic covariates on risk of root mortality. Cox analysis on the full dataset included the effects of all treatments (C, T, TD, $\left.\mathrm{TDCO}_{2}\right)$, year of appearance $(2006,2007,2008)$, season of appearance (growth season: spring + summer; dormant season: autumn + winter), root diameter classes, air temperature and SWC measured between the last date the roots were observed and date of disappearance. The model was fitted using a maximum likelihood method to estimate the regression parameters (parameter estimate) associated with each explanatory variable and calculating the standard error and a chi-square test to test the null hypothesis that each parameter estimate is equal to zero. The sign of the parameter estimate indicates whether the hazard of mortality decreases (negative sign) or increases (positive sign) as the covariate value increases. A conditional risk ratio (or hazard ratio) was also computed from the parameter estimates. This ratio has several interpretations depending on the nature of the covariate. For dichotomous covariates, such as season of appearance, which was assigned as growth season or dormant season, the risk ratio can be interpreted as the ratio of hazard in the dormant compared with the growth season, controlling for all other covariates. For quantitative covariates such as air temperature and SWC, subtracting one from the risk ratio and multiplying it by 100 gives the estimated percent change in the hazard of mortality associated with a one-unit change in the covariate, controlling for all other covariates (Allison 1995). Cox analyses were run using the PROC PHREG procedures of the SAS software package (v8.1, SAS Institute Inc., Cary, NC, USA).

\section{Results}

Soil water content

During the course of the experiment, values of soil water content (SWC) ranged between 0.04 and $0.14 \mathrm{~cm} \mathrm{~cm}^{-3}$ in the warmed site (T, TD and $\mathrm{TDCO}_{2}$ ) and between 0.08 and $0.15 \mathrm{~cm} \mathrm{~cm}^{-3}$ in the control site (C), leading to lower $(-18 \%, P<0.01)$ values in the warmed site (Fig. 1). However, due to large withintreatment variation, no between-treatment differences were found for T, TD and $\mathrm{TDCO}_{2}$ during study period. Irrespective of treatment, SWC values were lower in the summer period (particularly in 2006, a drier year than 2007 and 2008) and higher in winter and most SWC values fell within the range of soil water potential measured between field capacity and wilting point (1.5 MPa).

Root length growth rate and cumulative new root length

Over the three-year study, seasonal root growth rate was higher $(P<0.01)$ in the warmed site $(\mathrm{T}$, $\left.0.31 \mathrm{~mm} \mathrm{~cm}^{-2} \mathrm{day}^{-1}\right)$ than in the control site $(\mathrm{C}$, $0.23 \mathrm{~mm} \mathrm{~cm}^{-2}$ day $^{-1}$ ) (Fig. 2, Table 1), but the effects were more pronounced in spring 2007 and summer 2008. Cumulative new root length ranged from 490.9 (C treatment) to $650.3 \mathrm{~mm} \mathrm{~cm}^{-2}\left(\mathrm{TDCO}_{2}\right)$ with significant higher $(P<0.01)$ values in the warmed site $(\mathrm{C}$ vs $\mathrm{T}, 490.9$ vs $593.5 \mathrm{~mm} \mathrm{~cm}^{-2}$ ) and in the combined 


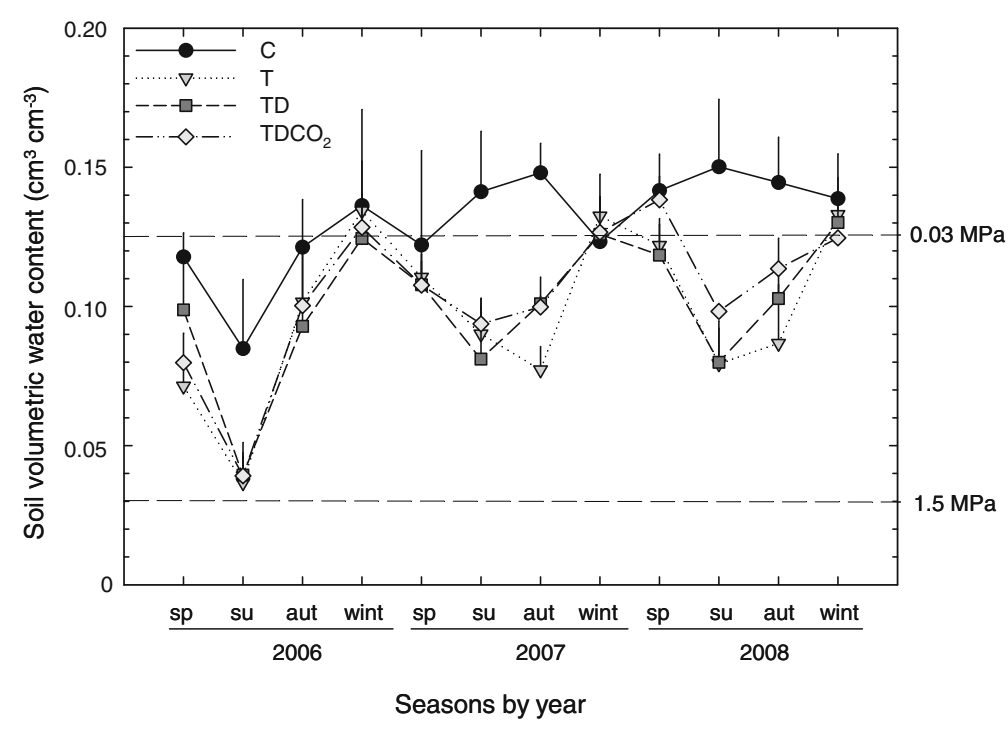

Fig. 1 Effects of climate treatment on seasonal variations in volumetric soil water content $(0-20 \mathrm{~cm})$. Treatment codes are as follows: $\mathrm{C}=$ control; $\mathrm{T}=$ elevated temperature $\left(+3.5^{\circ} \mathrm{C}\right), \mathrm{TD}=$ elevated temperature and summer precipitation reduction ($20 \%$ ); $\mathrm{TDCO}_{2}=$ elevated temperature, summer precipitation

climate change drivers $\left(\mathrm{C}\right.$ vs $\left.\mathrm{TDCO}_{2}\right)$ (Fig. 3, Table 1). On an annual basis, a significant warming effect (C vs T) on growth rate was observed for 2 years (2007 and 2008), whereas cumulative new root length was only higher in 2008 (Table 1). Similarly in combined

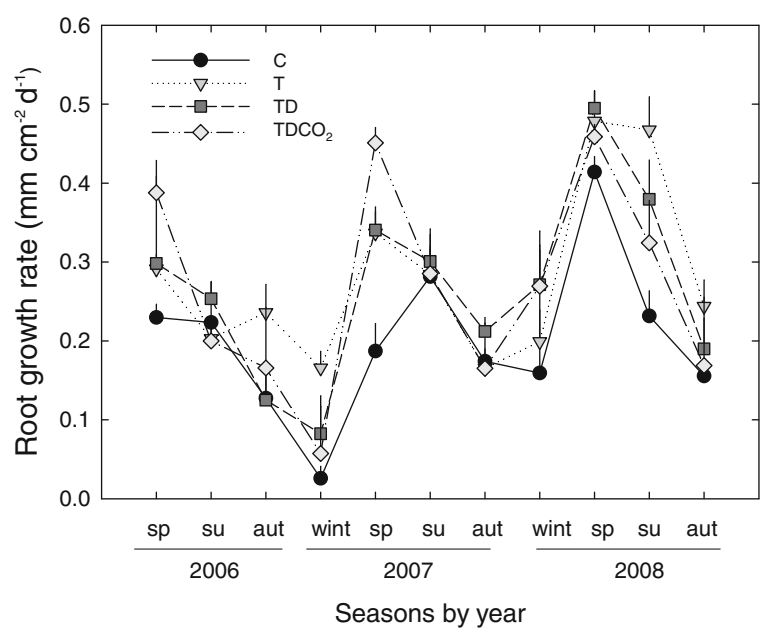

Fig. 2 Effects of climate treatment on seasonal dynamics in root growth rate. Treatment codes are as follows: $\mathrm{C}=$ control; $\mathrm{T}=$ elevated temperature $\left(+3.5^{\circ} \mathrm{C}\right)$, TD $=$ elevated temperature and summer precipitation reduction $(-20 \%) ; \mathrm{TDCO}_{2}=$ elevated temperature, summer precipitation reduction and $\mathrm{CO}_{2}$ enrichment $\left(+200 \mu \mathrm{mol} \mathrm{mol}{ }^{-1}\right)$. Vertical bars correspond to standard error $(n=5)$. sp = spring; $\mathrm{su}=$ summer; aut $=$ autumn; wint $=$ winter reduction and $\mathrm{CO}_{2}$ enrichment $\left(+200 \mu \mathrm{mol} \mathrm{mol}{ }^{-1}\right)$. Vertical bars correspond to standard error $(n=2-5)$. Horizontal lines correspond to value of soil water potential measured at field capacity $(0.03 \mathrm{MPa})$ and at wilting point $(1.5 \mathrm{MPa}) . \mathrm{sp}=$ spring; $\mathrm{su}=$ summer; aut $=$ autumn; wint $=$ winter

climate change drivers $\left(\mathrm{C}\right.$ vs $\left.\mathrm{TDCO}_{2}\right)$, root growth was higher $(P<0.05)$ in 2007 and new root length increased in 2007 and 2008. In contrast, summer precipitation reduction (T vs TD) and elevated $\mathrm{CO}_{2}$ (TD vs $\mathrm{TDCO}_{2}$ ) had no significant effect on growth rate and on cumulative new root length (Tables 1, 2, Figs. 2, 3).

Over the course of the experiment, growth rate and cumulative new root length showed strong seasonal and annual effects across all climate treatments (Fig. 2, Table 2): growth rates were higher in spring compared to summer and autumn-plus-winter $(+43 \%$ and $+140 \%$, respectively); and in summer growth rate was higher (+68\%) than in autumn and winter (Fig. 2).

Treatment effects on cumulative new root length varied depending on diameter class (significant treatment $\mathrm{x}$ class interaction, $P<0.001$, Table 2, Fig. 3). For the fine roots $(\leq 0.1 \mathrm{~mm})$, new root length increased from 70.1 to $135.9 \mathrm{~mm} \mathrm{~cm}^{-2}$ in response to air warming and from 7.1 to $114.1 \mathrm{~mm} \mathrm{~cm}^{-2}$ in response to combined climate change drivers. In contrast elevated $\mathrm{CO}_{2}$ (TD vs $\mathrm{TDCO}_{2}$ ) showed an opposite effect $\left(-28 \%, 158\right.$ vs $\left.114.1 \mathrm{~mm} \mathrm{~cm}^{-2}\right)$. In the case of the coarse roots $(>0.2 \mathrm{~mm})$, elevated $\mathrm{CO}_{2}$ and combined climate change drivers ( $\mathrm{C}$ vs $\left.\mathrm{TDCO}_{2}\right)$ increased new root length $(219.2$ vs 145.7 and 219.2 vs $136.5 \mathrm{~mm} \mathrm{~cm}^{-2}$, respectively), whereas 
Table 1 Effects of warming, summer precipitation reduction, elevated $\mathrm{CO}_{2}$ and combined climate change drivers (2080 climate scenario) on root length growth rate, cumulative new root length, mortality and standing root length measured during the three-year study period (all years). Treatment codes are as follows: $\mathrm{C}=$ control; $\mathrm{T}=$ elevated temperature $\left(+3.5{ }^{\circ} \mathrm{C}\right)$, $\mathrm{TD}=$ elevated temperature and summer precipitation reduction $(-20 \%) ; \mathrm{TDCO}_{2}=$ elevated temperature, summer precipitation reduction and $\mathrm{CO}_{2}$ enrichment $\left(+200 \mu \mathrm{mol} \mathrm{mol}^{-1}\right)$

\begin{tabular}{|c|c|c|c|c|c|c|c|c|c|}
\hline & \multirow[t]{3}{*}{ Year } & \multirow{2}{*}{\multicolumn{2}{|c|}{$\frac{\text { Warming }}{\mathrm{C} \text { vs T }}$}} & \multirow{2}{*}{\multicolumn{2}{|c|}{$\frac{\text { Summer precipitation reduction }}{\mathrm{T} \text { vs TD }}$}} & \multirow{2}{*}{\multicolumn{2}{|c|}{$\frac{\text { Elevated } \mathrm{CO}_{2}}{\text { TD vs } \mathrm{TDCO}_{2}}$}} & \multirow{2}{*}{\multicolumn{2}{|c|}{$\frac{2080 \text { climate scenario }}{\mathrm{C} \text { vs } \mathrm{TDCO}_{2}}$}} \\
\hline & & & & & & & & & \\
\hline & & $\mathrm{F}$ & $\mathrm{P}$ & $\mathrm{F}$ & $\mathrm{P}$ & $\mathrm{F}$ & $\mathrm{P}$ & $\mathrm{F}$ & $\mathrm{P}$ \\
\hline \multirow[t]{4}{*}{ Root growth rate $\left(\mathrm{mm} \mathrm{cm}^{-2} \mathrm{day}^{-1}\right)$} & 2006 & 0.69 & NS & 0.01 & NS & 0.19 & NS & 1.43 & NS \\
\hline & 2007 & 3.85 & $*$ & 0.15 & NS & 0.09 & NS & 4.05 & $*$ \\
\hline & 2008 & 7.39 & $* *$ & 0.13 & NS & 0.75 & NS & 3.11 & NS \\
\hline & All years & 10.05 & $* *$ & 0.05 & $\mathrm{NS}$ & 0.15 & NS & 7.19 & $* *$ \\
\hline \multirow[t]{4}{*}{ New root length $\left(\mathrm{mm} \mathrm{cm}^{-2}\right)$} & 2006 & 0.07 & NS & 0.47 & NS & 0 & NS & 0.37 & NS \\
\hline & 2007 & 3.41 & NS & 0.01 & NS & 2.4 & NS & 10.2 & $*$ \\
\hline & 2008 & 5.35 & $*$ & 0.33 & NS & 1.02 & NS & 7.22 & $*$ \\
\hline & All years & 5.25 & $*$ & 0.02 & NS & 0.98 & NS & 7.45 & $*$ \\
\hline \multirow[t]{4}{*}{ Mortality root length $\left(\mathrm{mm} \mathrm{cm}^{-2}\right)$} & 2006 & 0.51 & NS & 0.62 & NS & 0.49 & NS & 0.86 & NS \\
\hline & 2007 & 0.12 & NS & 0.36 & NS & 0.85 & NS & 0.46 & NS \\
\hline & 2008 & 0.03 & NS & 2.69 & NS & 0.13 & NS & 0.5 & NS \\
\hline & All years & 0.13 & NS & 0.33 & NS & 0 & NS & 0.79 & NS \\
\hline \multirow[t]{4}{*}{ Standing root length $\left(\mathrm{mm} \mathrm{cm}^{-2}\right)$} & 2006 & 0.07 & $\mathrm{NS}$ & 0.07 & $\mathrm{NS}$ & 0.6 & NS & 0.03 & NS \\
\hline & 2007 & 0.87 & NS & 0.41 & NS & 0.01 & NS & 4.34 & NS \\
\hline & 2008 & 4.71 & NS & 3.18 & NS & 5.72 & $*$ & 8.09 & $*$ \\
\hline & All years & 6.31 & $*$ & 1.01 & $\mathrm{NS}$ & 3.9 & NS & 19.4 & $* *$ \\
\hline
\end{tabular}

F is F-ratio, NS: $P>0.05 ; *: P \leq 0.05 ; * *: P \leq 0.01$

warming and summer precipitation reduction had no effect (Fig. 3). The intermediate diameter class $(0.1<$ $\mathrm{D} \leq 0.2 \mathrm{~mm}$ ) always exhibited higher root growth than fine (x 2.5) and coarse (x 1.8) roots, fine roots having the lowest new root length (Fig. 3).

Root length mortality based on disappearance

Over the three year-study, climate treatment had no overall effect on cumulative root length mortality, but varied with diameter class (significant treatment $\mathrm{x}$ class interaction, $P<0.001$, Table 2, Fig. 3). For fine roots $(\leq 0.1 \mathrm{~mm})$, root length mortality increased $(P<0.001)$ in response to warming $(75 \%)$ and ranged from 56.8 (treatment $C$ ) to $99.2 \mathrm{~mm} \mathrm{~cm}^{-2}$ (treatment $\mathrm{T}$ ) and also increased in response to summer precipitation reduction ( $\mathrm{T}$ vs $\mathrm{TD}, 99.2$ to $137.7 \mathrm{~mm} \mathrm{~cm}^{-2}$ ). In contrast, elevated $\mathrm{CO}_{2}$ had an opposite effect (74.4 vs $137.7 \mathrm{~mm} \mathrm{~cm}^{-2}$ ), and combined climate change driver showed no effect. For coarse roots $(>0.2 \mathrm{~mm})$, elevated $\mathrm{CO}_{2}$ (TD vs $\mathrm{TDCO}_{2}$, $62.4 \mathrm{vs} 103 \mathrm{~mm} \mathrm{~cm}^{-2}$ ) and combined climate change drivers (C vs $\mathrm{TDCO}_{2}, 62.8$ vs $103 \mathrm{~mm} \mathrm{~cm}^{-2}$ ) increased root mortality, whereas warming and summer precipitation reduction had no effect (Fig. 3).

\section{Standing root length}

Standing root length ranged between 201 and $305 \mathrm{~mm} \mathrm{~cm}^{-2}$ in the $\mathrm{C}$ and $\mathrm{TDCO}_{2}$ treatments, respectively. Significant warming (C vs T, 201 vs $283.2 \mathrm{~mm} \mathrm{~cm}^{-2}$, $P<0.05)$ and combined climate change drivers ( $\mathrm{C}$ vs $\mathrm{TDCO}_{2}, 201$ vs $\left.305.3 \mathrm{~mm} \mathrm{~cm}^{-2}, P<0.01\right)$ effects were observed across diameter classes, while summer precipitation reduction ( $\mathrm{T}$ vs TD) and elevated $\mathrm{CO}_{2}$ (TD vs $\mathrm{TDCO}_{2}$ ) had no effect (Tables 1, 2; Fig. 3). Furthermore, across treatments and diameter classes, standing root length, was significantly higher in 2006 than in 2007 and 2008 ( +178 and $+60 \%$, respectively) (Table 2). Only in 2008, elevated $\mathrm{CO}_{2}$ and combined climate change 
Fig. 3 Cumulative new root length, root length mortality and standing root length $\left(\mathrm{mm} \mathrm{cm}^{-2}\right)$ measured over 3 years for three diameter classes $(\leq 0.1 \mathrm{~mm}, 0.1<\mathrm{D} \leq$ $0.2 \mathrm{~mm},>0.2 \mathrm{~mm}$ ) and for all roots subjected to four treatments $\mathrm{C}, \mathrm{T}, \mathrm{TD}$,

$\mathrm{TDCO}_{2}$. Treatment codes are as follows: $\mathrm{C}=$ control; $\mathrm{T}=$ elevated temperature $\left(+3.5^{\circ} \mathrm{C}\right), \mathrm{TD}=$ elevated temperature and summer precipitation reduction $(-20 \%) ; \mathrm{TDCO}_{2}=$ elevated temperature, summer precipitation reduction and $\mathrm{CO}_{2}$ enrichment

$\left(+200 \mu \mathrm{mol} \mathrm{mol}{ }^{-1}\right)$. Vertical bars correspond to standard error $(n=5)$. Different letters correspond to statistical differences $(\mathrm{P} \leq 0.05)$. NS: $\mathrm{P}>0.05$
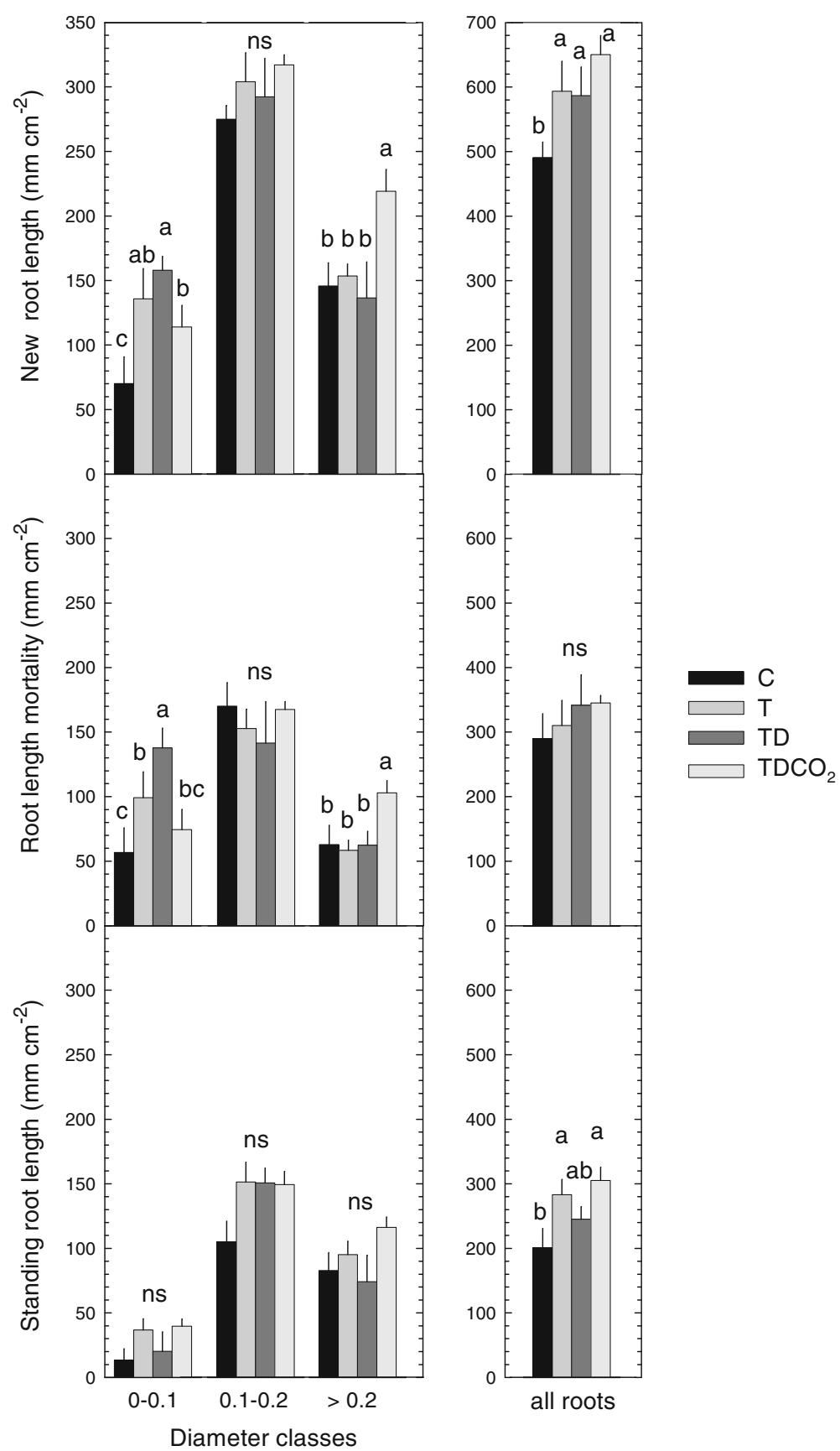

drivers significantly increased $(P<0.05)$ standing root length (Table 1).

Median root longevity based on root disappearance

Treatments and diameter classes significantly affected the median root longevity (MRL) given by KaplanMeier analysis (Table 3). MRL of all root types reached about 404 days in $\mathrm{C}$ and $\mathrm{TDCO}_{2}$ treatments, which showed significant higher values than $\mathrm{T}$ and $\mathrm{TD}$ treatments, 369 and 355 days, respectively. This trend was also observed for the fine roots, but with lower MRL: average values of 343 days for $\mathrm{C}$ and $\mathrm{TDCO}_{2}$, and 285 days for $\mathrm{T}$ and TD treatments. In the case of coarse roots $(>0.2 \mathrm{~mm})$, the effects of air warming on MRL was also observed in T and TD, but the future 
Table 2 Effects of climate treatment, root diameter classes and year on cumulative new root length, root length mortality and standing root length $\left(\mathrm{mm} \mathrm{cm}^{-2}\right)$ measured during the three-year study period

\begin{tabular}{|c|c|c|c|c|c|c|c|}
\hline Source & d.f. & $\mathrm{F}$ & New root length & $\mathrm{F}$ & Mortality root length & $\mathrm{F}$ & Standing root length \\
\hline Treatment & 3 & 5.3 & $* * *$ & 1.2 & NS & 3.0 & $*$ \\
\hline Diameter classes & 2 & 123.9 & $* * *$ & 43.2 & $* * *$ & 54.4 & $* * *$ \\
\hline Year & 2 & 7.0 & $* *$ & 31.5 & $* * *$ & 30.5 & $* * *$ \\
\hline Treatment x Classes & 6 & 3.0 & $* * *$ & 4.3 & $* * *$ & 0.7 & NS \\
\hline Treatment x Year & 6 & 0.7 & NS & 0.9 & NS & 1.7 & NS \\
\hline Classes x Year & 4 & 19.5 & $* * *$ & 9.8 & $* * *$ & 11.7 & $* * *$ \\
\hline Treatment x Classes $\mathrm{x}$ Year & 12 & 0.5 & NS & 0.6 & NS & 1.0 & NS \\
\hline
\end{tabular}

Significances of treatment, diameter classes, year and their interactions are indicated for the different variables; NS: $P>0.05 ; *: P \leq 0.05$; $* * *: P \leq 0.001$. d.f.: degree of freedom, F: F-ratio

climate treatment showed the lowest MRL (421 days). Furthermore, median root longevity was positively related with root diameter classes for three treatments (C, T, TD), while for the $\mathrm{TDCO}_{2}$ treatment MRL did not differ between root diameters (Table 3).

\section{Risk of root mortality based on root disappearance}

Across all root cohorts, treatment, year of appearance, diameter classes and SWC were significantly related to the risk of root mortality (Table 4). The sign of the parameter estimate indicates whether the hazard of mortality decreases (negative sign) or increases (positive sign) as the covariate value increases. Risk of mortality was significantly $(P<0.0001)$ lower in dry year $(2006)$ than in wet years $(2007,2008)$ and for coarse roots compared with fine roots. In addition, effect of treatments and of SWC was marginally significant $(P<0.05)$ : the risk of mortality decreased in

Table 3 Median root longevity (days) \pm standard error $(n=5)$ calculated from Kaplan-Meier analysis (50\% of surviving roots) and for three diameter classes $(\leq 0.1 \mathrm{~mm}, 0.1<\mathrm{D} \leq 0.2 \mathrm{~mm},>$ $0.2 \mathrm{~mm}$ ) and for all roots under different climate change treatments and for the three-year study period. Treatment
$\mathrm{TDCO}_{2}$ in comparison with $\mathrm{C}$ treatment and in case of high SWC values. However, season of appearance and air temperature had no effect on risk of root mortality.

\section{Discussion}

Grassland root responses to air warming and combined climate change drivers

A better understanding on ecosystem responses to multiple climate change drivers are needed to anticipate future ecosystem functioning and provision of ecosystem services. Given that roots represent the plant interface with the soil, it is crucial to gain deeper insight into root responses to climate change. Here we report root dynamics of a grassland ecosystem subjected to combined effects of air warming, reduction of summer precipitation and elevated atmospheric

codes are as follows: $\mathrm{C}=$ control; $\mathrm{T}=$ elevated temperature $\left(+3.5{ }^{\circ} \mathrm{C}\right)$, TD $=$ elevated temperature and summer precipitation reduction $(-20 \%) ; \mathrm{TDCO}_{2}=$ elevated temperature, summer precipitation reduction and $\mathrm{CO}_{2}$ enrichment $\left(+200 \mu \mathrm{mol} \mathrm{mol}{ }^{-1}\right)$

\begin{tabular}{llllll}
\hline Diameter classes & $\mathrm{C}$ & $\mathrm{T}$ & $\mathrm{TD}$ & $\mathrm{TDCO}_{2}$ & ANOVA \\
\hline$\leq 0.1 \mathrm{~mm}$ & $324 \pm 18 \mathrm{Ca}$ & $287 \pm 14 \mathrm{Bb}$ & $283 \pm 12 \mathrm{Bb}$ & $362 \pm 41 \mathrm{Aa}$ & $* *$ \\
$0.1<\mathrm{D} \leq 0.2 \mathrm{~mm}$ & $407 \pm 20 \mathrm{Ba}$ & $398 \pm 17 \mathrm{Ba}$ & $414 \pm 25 \mathrm{Ba}$ & $408 \pm 26 \mathrm{Aa}$ & $\mathrm{NS}$ \\
$>0.2 \mathrm{~mm}$ & $608 \pm 79 \mathrm{Aa}$ & $533 \pm 127 \mathrm{Ab}$ & $561 \pm 120 \mathrm{Ab}$ & $421 \pm 36 \mathrm{Ac}$ & $*$ \\
All roots & $403 \pm 16 \mathrm{a}$ & $369 \pm 14 \mathrm{~b}$ & $355 \pm 13 \mathrm{~b}$ & $404 \pm 18 \mathrm{a}$ & $* *$ \\
\hline
\end{tabular}

For each class, all roots and each treatment, different letters correspond to statistical differences (NS: $P>0.05 ; *: P \leq 0.05 ; * *: P \leq 0.01$.). Uppercase and lowercase letters correspond to comparison of diameter class per treatment and comparison of treatments per diameter class, respectively 
Table 4 Proportional hazards regression performed on pooled root lifespan data collected from 2006 to 2008 . The parameter estimate and chi-square statistic for each model covariate is shown, for the effects of all treatments

\begin{tabular}{llllrrr}
\hline Variable & d.f. & Parameter estimate & Standard error & $\chi^{2}$ value & P-value & Hazard ratio \\
\hline All treatments & 1 & -0.040 & 0.019 & 4.35 & $\mathbf{0 . 0 3 7}$ & 0.960 \\
Year of appearance & 1 & 0.857 & 0.033 & 676.41 & $<.0001$ & 2.356 \\
Season of appearance & 1 & 0.038 & 0.039 & 0.92 & 0.336 & 1.039 \\
Diameter classes & 1 & -0.313 & 0.029 & 112.80 & $<.0001$ & 0.731 \\
Air temperature & 1 & 0.005 & 0.003 & 2.71 & 0.099 & 1.005 \\
Volumetric soil water content & 1 & -0.016 & 0.007 & 6.16 & $\mathbf{0 . 0 1 3}$ & 0.984 \\
\hline
\end{tabular}

Significant P-values are shown in bold $(P<0.05)$. Parameter estimates $(\beta)$ can be interpreted as follows: for quantitative covariates such as air temperature or volumetric soil water content, a one-unit change in the covariate is associated with a $100[\exp (\beta)-1] \operatorname{percent}$ change in the hazard of mortality, controlling for other covariates. For dichotomous categorical covariates (e.g. coded 0 and 1 , season of appearance), the hazard ratio can be interpreted as the estimated hazard for roots with a value of 1 vs the estimated hazard for roots with a value of 0 (Allison 1995)

$\mathrm{CO}_{2}$ over 3 years. Our results show that root growth rate, measured in the most active root zone $(5-10 \mathrm{~cm})$, was sensitive to warming (C vs T) and to simultaneous application of warming, precipitation reduction and elevated $\mathrm{CO}_{2}\left(\mathrm{C}\right.$ vs $\left.\mathrm{TDCO}_{2}\right)$, leading to higher net root length production and consequently higher standing root length. This is in agreement with other studies showing that root growth is stimulated by warming (Fitter et al. 1998, 1999; Pregitzer et al. 2000; Wan et al. 2007; Bai et al. 2010). Notably, root growth mirrored the increase of springtime aboveground production (see Bloor et al. 2010), indicating that above and below-ground production increase simultaneously under warming, confirming our first hypothesis. In our experiment, air warming also extended the growing season to early spring and late autumn which explains the higher root growth in the warmed treatments in these periods. However 2 years after the onset of treatment the positive effect of air warming on the above-ground compartment was not sustained (Cantarel et al. 2012). This decline is possibly linked to acclimation of photosynthesis (Chapin et al. 1995; Shaw et al. 2002), induced by negative water balance index (P - PET) and lower SWC (Fig. 1). Thus maintenance of root growth stimulation induced by air warming may correspond to a shift of $\mathrm{C}$ allocation to roots at the expense of the above-ground compartment, in warmer and drier soil conditions.

Contrary to expectations, precipitation reduction had no effect on root growth and mortality, presumably due to relatively important soil moisture values, which indicated that no marked edaphic drought occurred during the study period (Fig. 1). Reduced soil moisture and subsequent limitation of nutrients under combined elevated $\mathrm{CO}_{2}$ and warming may explain the lack of response under elevated $\mathrm{CO}_{2}$ (Shaw et al. 2002; Luo et al. 2004, but see Hovenden et al. 2008). Positive effects of elevated $\mathrm{CO}_{2}$ may be reduced when combined with air warming and reduction of summer precipitation. Warming was, thus, the main climate factor shaping root system response of our upland perennial grassland.

Linking morphology, median root longevity and covariates associated with risk of root mortality based on disappearance

Root longevity is one of the most important variables for understanding belowground $\mathrm{C}$ cycling in ecosystems, as it determines how quickly $\mathrm{C}$ allocated to roots is transferred to microbial and soil $\mathrm{C}$ pools (Gill and Jackson 2000; Norby and Luo 2004). However, multiple effects of climate change on plants and their soil environment makes simple prediction of root longevity a difficult task (Eissenstat et al. 2000). This is further compounded by the numerous determinants of root longevity or root mortality (Eissenstat and Yanai 1997; Gill et al. 2002).

Consequently, identifying determinants of root mortality and root longevity and predicting source/ sink ecosystem activity under future climate scenarios remains a complex challenge. One of the most cited determinants of root longevity is diameter, with coarse roots demonstrating higher longevity than fine roots (Eissenstat and Yanai 1997; Gill et al. 2002). Our data confirmed these previous studies for three of the four treatments (C, T, TD) (Tables 3, 4). This may be 
because thicker roots function as conduits and initiate new laterals, and are thus probably preferentially retained by the plant (Wells and Eissenstat 2001). They are also more suberized with more lignified cell walls in cortex or stele than fine roots, increasing their defence against herbivores or pathogens. Overall this contributes to increase their longevity. However the decrease in longevity of coarse roots and increase of fine root longevity observed under elevated $\mathrm{CO}_{2}$ were unexpected. This is a novel finding that raises questions on the contrasted functioning under elevated $\mathrm{CO}_{2}$ of these extreme root classes that together represent about $45 \%$ of total root length. The faster turnover of the coarse roots can be due to higher foraging activity in depleted resource patches and to replacing them with more active roots in new soil sites. This would explain the higher rhizosphere activity for coarse roots grown under elevated $\mathrm{CO}_{2}$, as suggested in earlier study (Hungate et al. 1997). Milchunas et al. (2005a) also suggested that the higher diameter of roots grown under elevated $\mathrm{CO}_{2}$ may be related to their water status. If these roots have higher water content, i.e. low dry matter content, we would also expect lower root tissue density and consequently lower root lifespan (Ryser 1998). In contrast, combined effects of warming and elevated $\mathrm{CO}_{2}$ may have induced higher carbohydrate and nitrogen contents in the tissues of fine roots, which in turn may increase their lifespan (see Farrar and Williams 1991).

Air warming (C vs $\mathrm{T}$ treatment) significantly reduced root longevity, irrespective of diameter class, thus confirming previous results obtained in grasslands (Forbes et al. 1997; Fitter et al. 1998, 1999). Nevertheless, fine roots were more prone to mortality in warmed treatments than other diameter class roots, which confirm our hypothesis on the lifespan sensitivity of fine roots. The sensitivity could be explained by indirect effects of reduced soil water content due to higher plant evapotranspiration demand and lower water balance index. Indeed, our study revealed effects of soil water content on the risk of root mortality, depending on year, diameter class, and treatment (Table 4). These results suggest the importance of soil moisture in shaping the risk of root mortality in warmer seasons and drier years for upland grasslands, with fine roots being particularly sensitive. Root sensitivity to both average climate (comparison of $\mathrm{C}$ with $\mathrm{T}, \mathrm{TD}$ and $\mathrm{TDCO}_{2}$ ) and climatic variability (between-year and betweenseason differences) showed a strong difference depending on root diameter class, indicating that not all the grassland root system is similarly affected by climate change components. This may have consequences on plant and soil relationships, especially root and microbe activities that are critical for the decomposition of soil organic matter and its mineralization in future climates (Zak et al. 2000).

Seasonal dynamics of perennial grassland root system

Our study confirms the importance of seasonality in grassland ecosystem root dynamics (Matthew et al. 1991; Fitter et al. 1998; Steinaker and Wilson 2008; Garcia-Pausas et al. 2011). Global radiation and air temperature are the main abiotic determinants of root growth in perennial grasslands not limited by water inputs (Edwards et al. 2004), because of the rapid transfer of photosynthates to roots in grassland ecosystem (Kuzyakov and Gavrichkova 2010). This is confirmed by the fact that the year 2006, for which we measured higher standing root length, was warmer $\left(+0.7{ }^{\circ} \mathrm{C}\right)$ and more sunny $(+10 \%)$ particularly during the growing season compared with 2007 and 2008. However disentangling the respective role of radiation flux and of temperature is difficult due to their tight relationship. In addition, our results may reflect plant ontogeny patterns (i.e. species-specific differences in phenology, Pontes et al. 2007), as it is likely that not all species responded at the same time and at the same rate to the climate treatments applied here. While species number was unaffected by the treatments, abundance of grasses declined from $98 \%$ to $89 \%$ in favour of legumes in the warmed site in comparison with the control site (Cantarel et al. 2012). These changes are expected to affect ecosystem functioning both at above and below-ground levels, but due to the impossibility to recognise species or functional group from minirhizotron images, it was not possible to assess directly its effect on root dynamics. Finally, this data set shows that grassland root system response to multiple climate change drivers is mainly driven by intra and inter-annual climate variability, which may in turn control the dynamic of plant functional diversity activity and confirms the third hypothesis. 


\section{Conclusions}

Here, we report changes in root dynamics, longevity and morphology of grassland monoliths submitted to air warming and simultaneous application of warming, summer precipitation reduction and elevated $\mathrm{CO}_{2}$ over 3 years. Our results suggest that under warmer climates and the future IPCC A2 scenario, upland grassland ecosystems may increase their total root system length but lose a proportion of their fine roots growing in the upper soil layer. This underlines the importance of studying root diameter class responses in climate change experiments. Our finding also show that climate variability, both at inter- and intra-annual scales, mediates grassland root responses under both current and future climate scenarios, and may mask clear patterns of response to climate drivers. Future studies should examine whether climate-induced impacts of root dynamics may increase soil $\mathrm{C}$ storage in the long term and for deeper soil layers.

Acknowledgements We thank Patrick Pichon, Nicolas Deltroy, Amélie Cantarel for their help with data collection and site management during the study period. Katja Klumpp is acknowledged for improving a previous version of the paper. This study received financial support via a doctoral fellowship from the Region Auvergne and the INRA (EFPA Department) awarded to RP, a CNRS postdoctoral fellowship awarded to JMGB, an IFBGICC project grant, an ANR [French national research agency] project grant, and the EC FP6 'NitroEurope-IP' project.

\section{References}

Allison PD (1995) Survival analysis using SAS. A practical guide. SAS Institute Inc., Cary

Anderson LJ, Derner JD, Polley HW, Gordon WS, Eissenstat DM, Jackson RB (2010) Root responses along a subambient to elevated $\mathrm{CO}_{2}$ gradient in a $\mathrm{C} 3-\mathrm{C} 4$ grassland. Glob Chang Biol 16:454-468

Arnone JA III, Zaller JG, Spehn EM, Niklaus PA, Wells CE, Korner C (2000) Dynamics of root systems in native grasslands: effects of elevated atmospheric $\mathrm{CO}_{2}$. New Phytol 147:73-85

Bahn M, Knapp M, Garajova Z, Pfahringer N, Cernusca A (2006) Root respiration in temperate mountain grasslands differing in land use. Glob Chang Biol 12:995-1006

Bai W, Wan S, Niu S et al (2010) Increased temperature and precipitation interact to affect root production, mortality, and turnover in a temperate steppe: implications for ecosystem C cycling. Glob Chang Biol 16:1306-1316

Bloor JMG, Pichon P, Falcimagne R, Leadley P, Soussana JF (2010) Effects of warming, summer drought, and $\mathrm{CO}_{2}$ enrichment on aboveground biomass production, flowering phenology, and community structure in an upland grassland ecosystem. Ecosystems 13:888-900

Cantarel A, Bloor JMG, Soussana JF (2012) Four years of simulated climate change reduces aboveground productivity and alters functional diversity in grassland. J Veg Sci, in press

Chapin FS, Shaver GR, Giblin AE, Nadelhoffer KJ, Laundre JA (1995) Responses of Arctic tundra to experimental and observed changes in climate. Ecology 76:694-711

Cox D (1972) Regression models and life tables. J Roy Stat Soc 34:187-220

Craine JM, Tilman D, Wedin D, Reich P, Tjoelker M, Knops J (2002) Functional traits, productivity and effects on nitrogen cycling of 33 grassland species. Funct Ecol 16:563-574

De Boeck HJ, Lemmens CMHM, Gielen B et al (2007) Combined effects of climate warming and plant diversity loss on above- and below-ground grassland productivity. Env Exp Bot 60:95-104

Dukes JS, Chiariello NR, Cleland EE et al (2005) Responses of grassland production to single and multiple global environmental changes. Plos Biol 3:1829-1837

Edwards EJ, Benham DG, Marland LA, Fitter AH (2004) Root production is determined by radiation flux in a temperate grassland community. Glob Chang Biol 10:209-227

Eissenstat DM, Yanai RD (1997) The ecology of root lifespan. Adv Ecol Res 27:1-60

Eissenstat DM, Wells CE, Yanai RD, Whitbeck JL (2000) Building roots in a changing environment: Implications for root longevity. New Phytol 147:33-42

Farrar JF, Williams ML (1991) The Effects of increased atmospheric carbon dioxide and temperature on carbon partitioning, source-sink relations and respiration. Plant Cell Environ 14:819-830

Fitter AH (1987) An architectural approach to the comparative ecology of plant-root systems. New Phytol 106:61-77

Fitter AH, Self GK, Wolfenden J, Vanvuuren MMI, Brown TK, Williamson L, Graves JD, Robinson D (1996) Root production and mortality under elevated atmospheric carbon dioxide. Plant Soil 187:299-306

Fitter AH, Graves JD, Wolfenden J, Self GK, Brown TK, Bogie D, Mansfield TA (1997) Root production and turnover and carbon budgets of two contrasting grasslands under ambient and elevated atmospheric carbon dioxide concentrations. New Phytol 137:247-255

Fitter AH, Graves JD, Self GK, Brown TK, Bogie DS, Taylor K (1998) Root production, turnover and respiration under two grassland types along an altitudinal gradient: influence of temperature and solar radiation. Oecologia 114:20-30

Fitter AH, Self GK, Brown TK, Bogie DS, Graves JD, Benham D, Ineson P (1999) Root production and turnover in an upland grassland subjected to artificial soil warming respond to radiation flux and nutrients, not temperature. Oecologia 120:575-581

Forbes PJ, Black KE, Hooker JE (1997) Temperature-induced alteration to root longevity in Lolium perenne. Plant Soil 190:87-90

Garcia-Pausas J, Casals P, Romanyà J, Vallecillo S, Sebastià M$\mathrm{T}$ (2011) Seasonal patterns of belowground biomass and productivity in mountain grasslands in the Pyrenees. Plant Soil 340:315-326

Gill AR, Jackson RB (2000) Global patterns of root turnover for terrestrial ecosystems. New Phytol 147:13-31 
Gill RA, Burke IC, Lauenroth WK, Milchunas DG (2002) Longevity and turnover of roots in the shortgrass steppe: Influence of diameter and depth. Plant Ecol 159:241-251

Higgins PAT, Jackson RB, Des Rosiers JM, Field CB (2002) Root production and demography in a California annual grassland under elevated atmospheric carbon dioxide. Glob Chang Biol 8:841-850

Hovenden MJ, Newton PCD, Carran RA et al (2008) Warming prevents the elevated $\mathrm{CO}_{2}$-induced reduction in available soil nitrogen in a temperate, perennial grassland. Glob Chang Biol 14:1018-1024

Hungate BA, Holland EA, Jackson RB, Chapin FS III, Mooney HA, Field CB (1997) The fate of carbon in grasslands under carbon dioxide enrichment. Nature 388:576-578

IPCC (2007) Climate Change 2007: the physical science basis. In: Solomon S, Qin D, Manning M, Chen Z, Marquis M, Averyt KB, Tignor M, Miller HL (eds) Contribution of working group I to the fourth assessment report of the Intergovernmental Panel on Climate Change. Cambridge University Press, Cambridge

Jackson RB, Caldwell MM (1996) Integrating resource heterogeneity and plant plasticity: modelling nitrate and phosphate uptake in a patchy soil environment. J Ecol 84:891-903

Johnson MG, Tingey DT, Phillips DL, Storm MJ (2001) Advancing fine root research with minirhizotrons. Environ Exp Bot 45:263-289

Kandeler E, Tscherko D, Bardgett RD, Hobbs PJ, Kampichler C, Jones TH (1998) The response of soil microorganisms and roots to elevated $\mathrm{CO}_{2}$ and temperature in a terrestrial model ecosystem. Plant Soil 202:251-262

Kuzyakov Y, Gavrichkova O (2010) REVIEW: time lag between photosynthesis and carbon dioxide efflux from soil: a review of mechanisms and controls. Glob Chang Biol 16:3386-3406

LeCain D, Morgan J, Milchunas D, Mosier A, Nelson J, Smith D (2006) Root biomass of individual species, and root size characteristics after 5 years of $\mathrm{CO}_{2}$ enrichment on native shortgrass steppe. Plant Soil 279:219c228

Louault F, Pillar VD, Aufrere J, Garnier E, Soussana JF (2005) Plant traits and functional types in response to reduced disturbance in a semi-natural grassland. J Veg Sci 16:151-160

Luo Y (2007) Terrestrial carbon cycle feedback to climate warming. Annu Rev Ecol Evol Syst 38:683-712

Luo Y, Su B, Currie WS, Dukes JS, Finzi A, Hartwig U, Hungate B, Mcnurtrie RE, Oren R, Parton WJ, Pataki DE, Shaw MR, Zak DR, Field CB (2004) Progressive nitrogen limitation of ecosystem responses to rising atmospheric carbon dioxide. BioScience 54:731-739

Luo Y, Gerten D, Le Maire G et al (2008) Modeled interactive effects of precipitation, temperature, and $\left[\mathrm{CO}_{2}\right]$ on ecosystem carbon and water dynamics in different climatic zones. Glob Chang Biol 14:1986-1999

Matthew C, Xia JX, Chu ACP, Mackay AD, Hodgson J (1991) Relationship between root production and tiller appearance rates in perennial ryegrass (Lolium perenne L.). In: Atkinson D (ed) Plant root growth - an ecological perspective. Blackwell Science Publications, Oxford, pp 281-290

Miglietta F, Peressotti A, Vaccari FP, Zaldei A, deAngelis P, Scarascia-Mugnozza G (2001) Free-air $\mathrm{CO}_{2}$ enrichment (FACE) of a poplar plantation: the POPFACE fumigation system. New Phytol 150:465-476
Milchunas D (2009) Estimating root production: comparison of 11 methods in shortgrass steppe and review of biases. Ecosystems 12:1381-1402

Milchunas DG, Morgan JA, Mosier AR, LeCain DR (2005a) Root dynamics and demography in shortgrass steppe under elevated $\mathrm{CO}_{2}$, and comments on minirhizotron methodology. Glob Chang Biol 11:1837-1855

Milchunas DG, Mosier AR, Morgan JA, LeCain DR, King JY, Nelson JA (2005b) Root production and tissue quality in a shortgrass steppe exposed to elevated $\mathrm{CO}_{2}$ : Using a new ingrowth method. Plant Soil 268:111-122

Niklaus PA, Spinnler D, Körner C (1998) Soil moisture dynamics of calcareous grassland under elevated $\mathrm{CO}_{2}$. Oecologia 117:201-208

Norby RJ, Jackson RB (2000) Root dynamics and global change: seeking an ecosystem perspective. New Phytol 147:3-12

Norby RJ, Luo Y (2004) Evaluating ecosystem responses to rising atmospheric $\mathrm{CO}_{2}$ and global warming in a multifactor world. New Phytol 162:281-293

Pendall E, Bridgham S, Hanson PJ et al (2004) Below-ground process responses to elevated $\mathrm{CO}_{2}$ and temperature: a discussion of observations, measurement methods, and models. New Phytol 162:311-322

Pendall E, Osanai YUI, Williams AL, Hovenden MJ (2011) Soil carbon storage under simulated climate change is mediated by plant functional type. Glob Chang Biol 17:505-514

Picon-Cochard C, Pilon R, Tarroux E, Pagès L, Robertson J, Dawson L (2012) Effects of species, root branching order and season on the root traits of 13 perennial grass species. Plant Soil 353:47-57

Pierret A, Doussan C, Capowiez Y, Bastardie F, Pages L (2007) Root functional architecture: a framework for modeling the interplay between roots and soil. Vadose Zone J 6:269-281

Pontes LS, Carrere P, Andueza D, Louault F, Soussana JF (2007) Seasonal productivity and nutritive value of temperate grasses found in semi-natural pastures in Europe: responses to cutting frequency and n supply. Grass For Sci 6:485-496

Pregitzer KS, King JA, Burton AJ, Brown SE (2000) Responses of tree fine roots to temperature. New Phytol 147:105-115

Ryser P (1998) Intra- and interspecific variation in root length, root turnover and the underlying parameters. In: Poorter $\mathrm{H}$, Van Vuuren MMI, Lambers H (eds) Inherent variation in plant growth. Physiological mechanisms and ecological consequences. Backhuys Publishers, Leiden, pp 441-465

Shaw MR, Zavaleta ES, Chiariello NR, Cleland EE, Mooney HA, Field CB (2002) Grassland responses to global environmental changes suppressed by elevated $\mathrm{CO}_{2}$. Science 298:1987-1990

Sindhøj E, Andren O, Katterer T, Marissink M, Pettersson R (2004) Root biomass dynamics in a semi-natural grassland exposed to elevated atmospheric $\mathrm{CO}_{2}$ for 5 years. Acta Agri Scandin Sect B-Soil Plant Sci 54:50-59

Soussana JF, Casella E, Loiseau P (1996) Long-term effects of $\mathrm{CO}_{2}$ enrichment and temperature increase on a temperate grass sward. 2. Plant nitrogen budgets and root fraction. Plant Soil 182:101-114 
Steinaker DF, Wilson SD (2005) Belowground litter contributions to nitrogen cycling at a northern grassland-forest boudary. Ecology 86:2825-2833

Steinaker DF, Wilson SD (2008) Phenology of fine roots and leaves in forest and grassland. J Ecol 96:1222-1229

Waisel Y, Eishel A (2002) Functional diversity of various constituents of a single root system. In: Waisel Y, Eshel A, Kafkafi U (eds) Plant roots: the hidden half, 3rd edn. Marcel Dekker, New York, pp 157-174

Wan S, Norby RJ, Ledford J, Weltzin JF (2007) Responses of soil respiration to elevated $\mathrm{CO}_{2}$, air warming, and changing soil water availability in a model old-field grassland. Glob Chang Biol 13:2411-2424
Wells CE, Eissenstat DM (2001) Marked differences in survivorship among apple roots of different diameters. Ecology 82:882-892

Wullschleger SD, Tschaplinski TJ, Norby RJ (2002) Plant water relations at elevated $\mathrm{CO}_{2}$-implications for water-limited environments. Plant Cell Environ 25:319-331

Zak DR, Pregitzer KS, King JS, Holmes WE (2000) Elevated atmospheric $\mathrm{CO}_{2}$, fine roots and the response of soil microorganisms: a review and hypothesis. New Phytol 147:201-222

Zhou X, Weng E, Luo Y (2008) Modeling patterns of nonlinearity in ecosystem responses to temperature, $\mathrm{CO} 2$ and precipitation changes. Ecol Appl 18:453-466 